\title{
An Unusual Caddo Bottle from the Walters Collection
}

\section{Mark Walters}

Heritage Research Center, Stephen F. Austin State University

Follow this and additional works at: https://scholarworks.sfasu.edu/ita

Part of the American Material Culture Commons, Archaeological Anthropology Commons, Environmental Studies Commons, Other American Studies Commons, Other Arts and Humanities Commons, Other History of Art, Architecture, and Archaeology Commons, and the United States History Commons

Tell us how this article helped you.

This Article is brought to you for free and open access by the Center for Regional Heritage Research at SFA ScholarWorks. It has been accepted for inclusion in Index of Texas Archaeology: Open Access Gray Literature from the Lone Star State by an authorized editor of SFA ScholarWorks. For more information, please contact cdsscholarworks@sfasu.edu. 


\section{An Unusual Caddo Bottle from the Walters Collection}

Creative Commons License

(c) (i) (8)

This work is licensed under a Creative Commons Attribution-NonCommercial 4.0 International License 


\section{An Unusual Caddo Bottle from the Walters Collection}

\section{Mark Walters}

In this article, I discuss an unusual Caddo bottle in the Walters Collection (Figures 1a-c). This vessel came from either Smith or Wood counties, Texas. The design on the bottle appears to depict a deer body with a human head. My purpose is to look at the vessel in more depth, explore the relationship between Caddo people and deer, and make information about the vessel available to the public. Plans are in place to curate this vessel at the Texas Archeological Research Laboratory at The University of Texas at Austin.

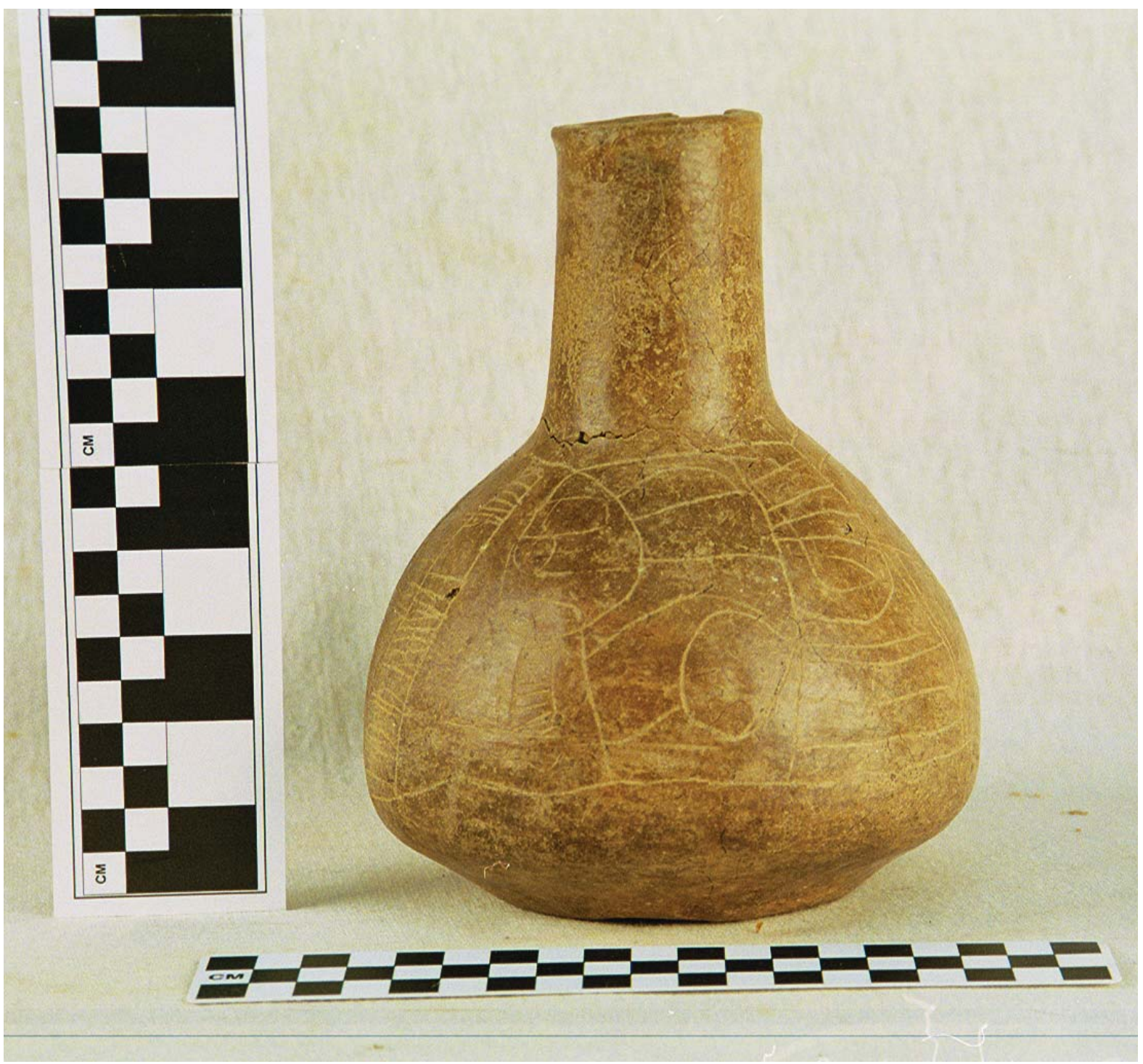

Figure 1a. Photograph showing entire design around bottle body.

Perttula et al. (2009) previously described the vessel: 


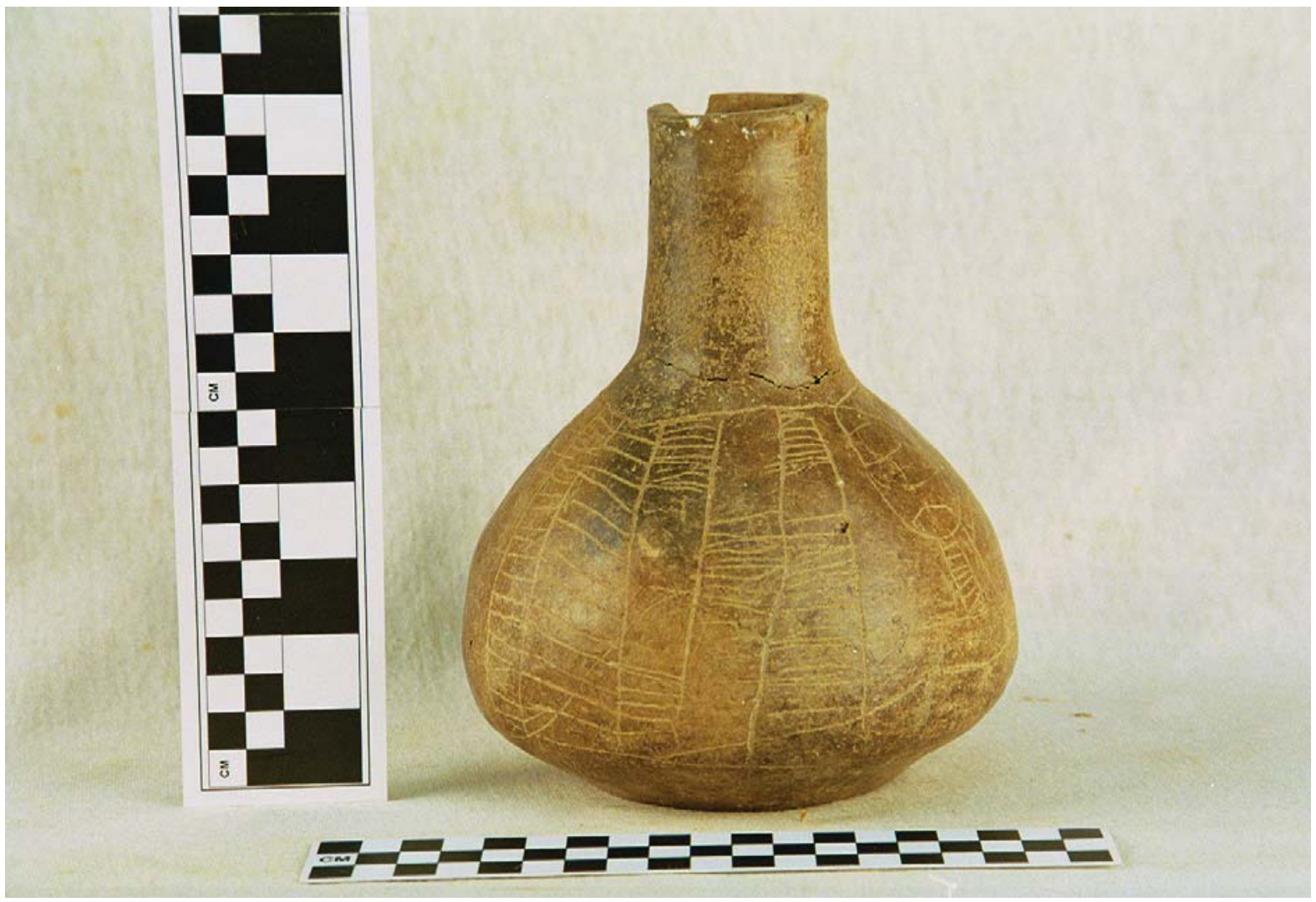

Figure 1b. Photograph showing entire design around bottle body.

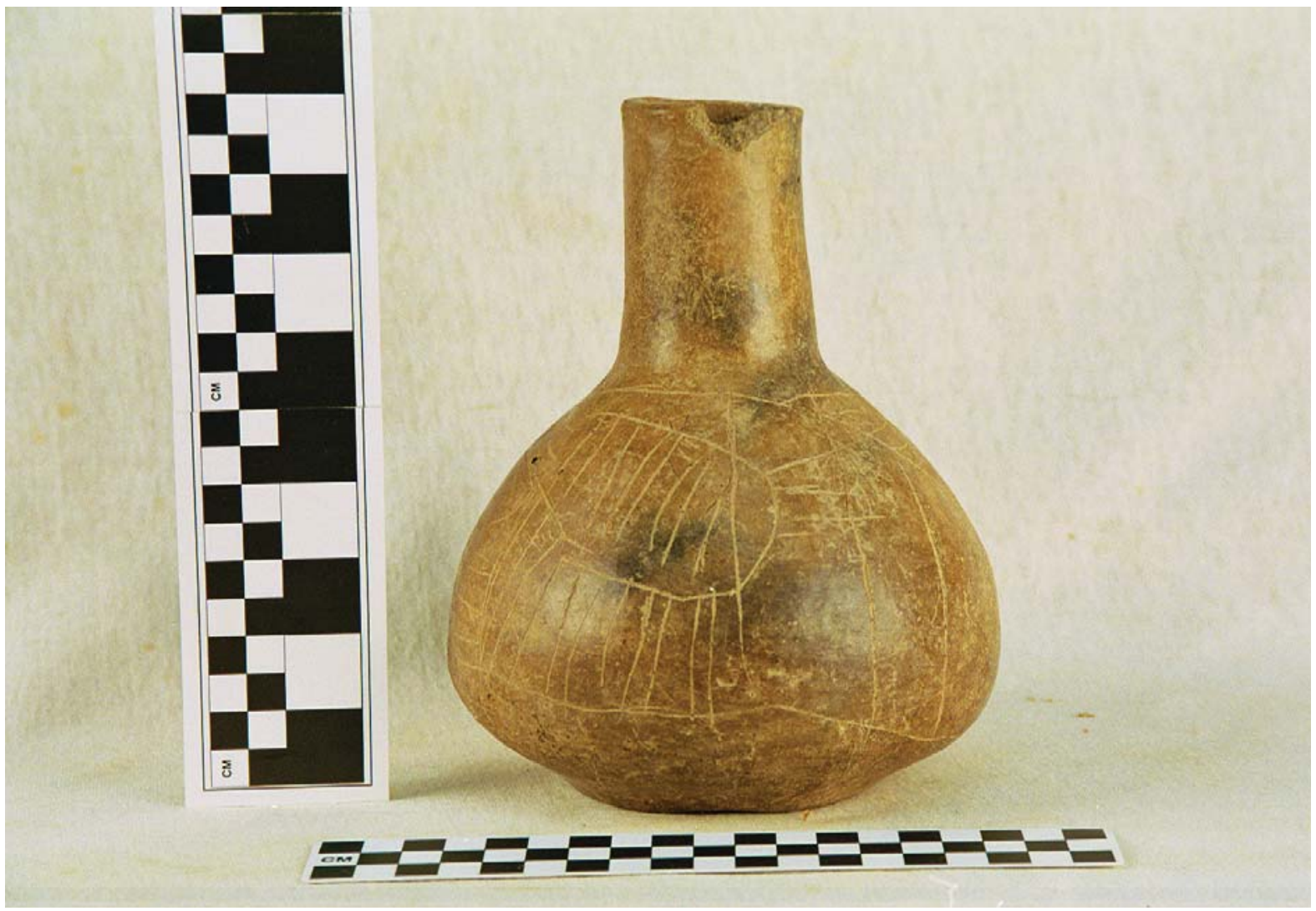

Figure 1c. Photograph showing entire design around bottle body. 
SITE NAME OR SITE NUMBER: Unknown

VESSEL NO.: 60

NON-PLASTICS: grog

VESSEL FORM: Bottle with a straight neck

RIM AND LIP FORM: Direct rim with a flat, exterior folded, lip

CORE COLOR: N/A

INTERIOR SURFACE COLOR: N/A

EXTERIOR SURFACE COLOR: dark yellowish-brown (10YR 4/4)

WALL THICKNESS (RIM, BODY, AND BASE IN MM: 6.7 mm, neck

INTERIOR SURFACE TREATMENT: smoothed on the upper neck

EXTERIOR SURFACE TREATMENT: burnished

HEIGHT (IN CM): 18.0

ORIFICE DIAMETER (IN CM): 4.5

DIAMETER AT BOTTOM OF RIM OR NECK (IN CM): $5.3 ; 14.3 \mathrm{~cm}$ is the maximum body width

BASE DIAMETER (IN CM): 8.0

ESTIMATED VOLUME (IN LITERS): 0.58

DECORATION: There are a series of engraved panels on the vessel body. Most of these panels are filled with irregularly-spaced horizontal engraved lines (Perttula et al. 2009a:Figure 209a), although two panels are plain and a third has only a few short horizontal and diagonal engraved lines. In the central panels are motifs that resemble an engraved human face (Perttula et al. 2009:Figure 209b) and the body of a quadruped (Perttula et al. 2009:Figure 209c).

TYPE: Unknown engraved fine ware vessel

Figure 2 is a drawing made at the time the vessel was documented by Perttula et al. (2009). Figure 3 shows the vessel in an expanded form, illustrating the continuous design around the bottle body. Fellow member of the Texas Archeological Stewardship Network (TASN) Bryan Boyd, and his wife Karen, provided a color and black/gray drawing of the design (Figures 4a-b) to better illustrate the unusual figure. The figure represented appears to be that of a deer body, complete with legs and tail, and a human face, perhaps with a beard or goatee. The dividing elements are hatched ladder designs that are common elements of Middle Caddo period (A.D. 1200-1400) ceramic assemblages in East Texas. This time period is marked by an expansion in the diversity of designs on Caddo vessels, but zoomorphic or human figures seldom occur as decorative elements. 


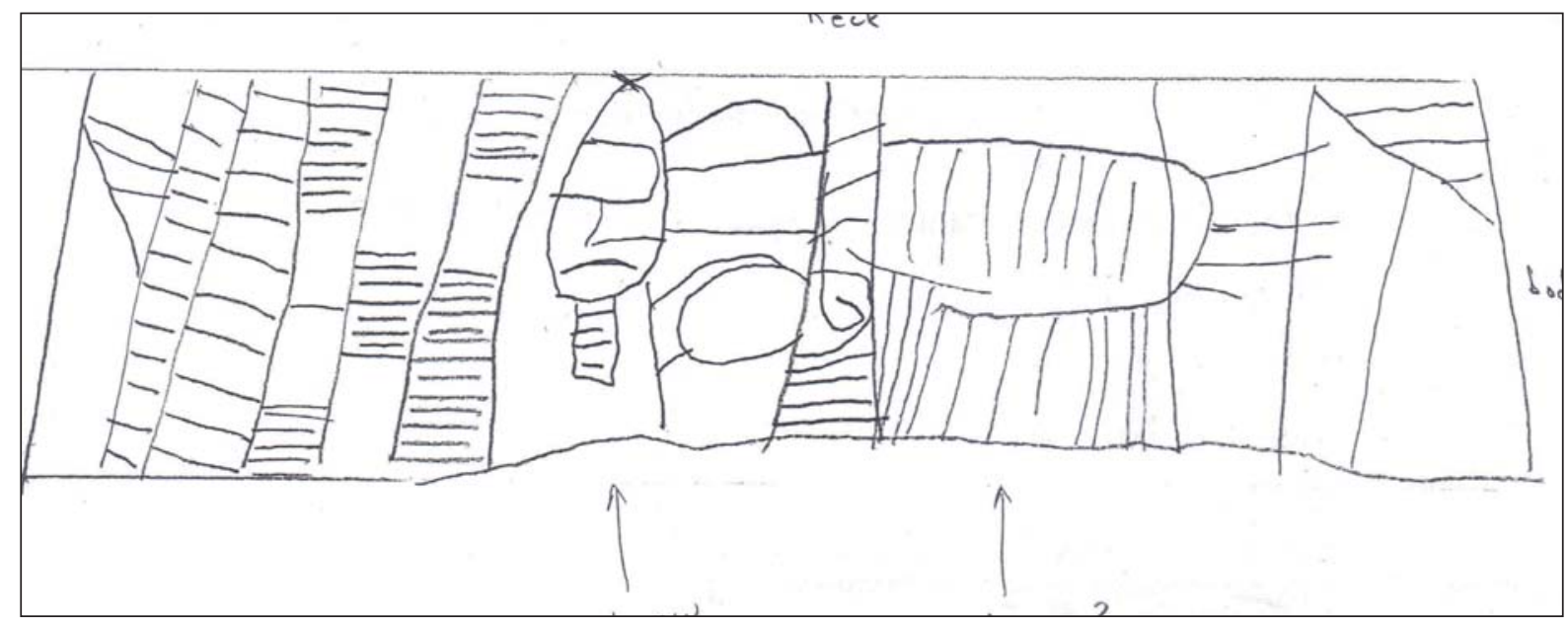

Figure 2. Drawing accompanying vessel recordation form.

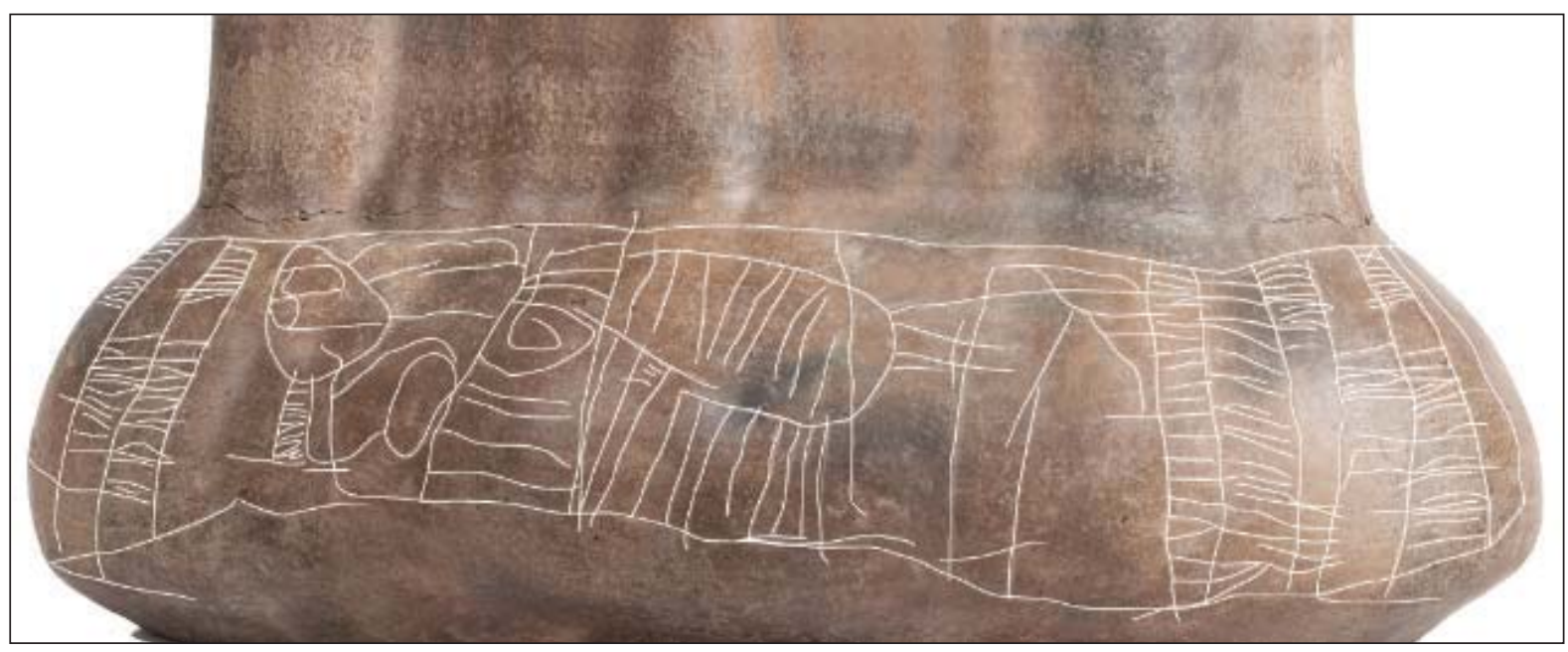

Figure 3. Expanded photo showing entire motif.

\section{Conclusions}

Deer certainly played an important role in Native American lifeways and history, and this is also the case for the white-tailed deer in the Caddo area. Throughout most of Caddo history, the favorite game animal hunted by Caddo men was the white-tailed deer. Deer provided most of the meat as well as hides, antlers, sinew, and bones for tools and clothing. But, more than a source of food, the relationship between the Caddo and deer was more complex than early Europeans realized. Deer also figured prominently in Caddo dance and symbolism.

Apparently universal among the Native Americans of North America was the idea that animals expect people to treat them right, and are capable of taking revenge if they do not (Driver 1961:80; Underhill 1967). They believed that if any hunter failed to perform these rituals and observe these taboos the deer would withhold themselves from all hunters, and might retaliate in other ways as well. The Caddo peoples of East Texas would not skin a deer unless a shaman was present to perform the proper rituals, even if waiting meant that the meat would spoil (Griffith 1954:116). As a tribe of hunters and farmers, Caddo religious ceremonies honored animal spirits and forces of nature. The night before a deer hunt a Caddo priest performed a ceremony involving a deer head and antlers: if the next day's hunt was successful then the hunters waited to butcher their kill until the priest had whispered in its ear. 


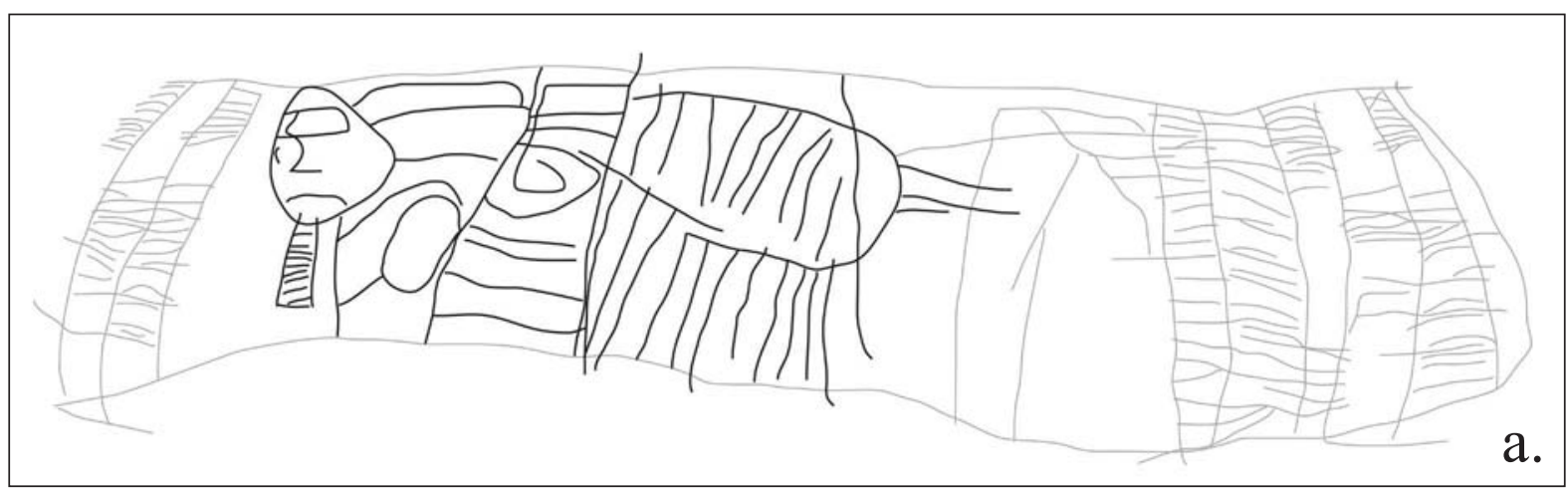

Figure 4. Highlighting decoration (a-b) to better view the engraved motif.

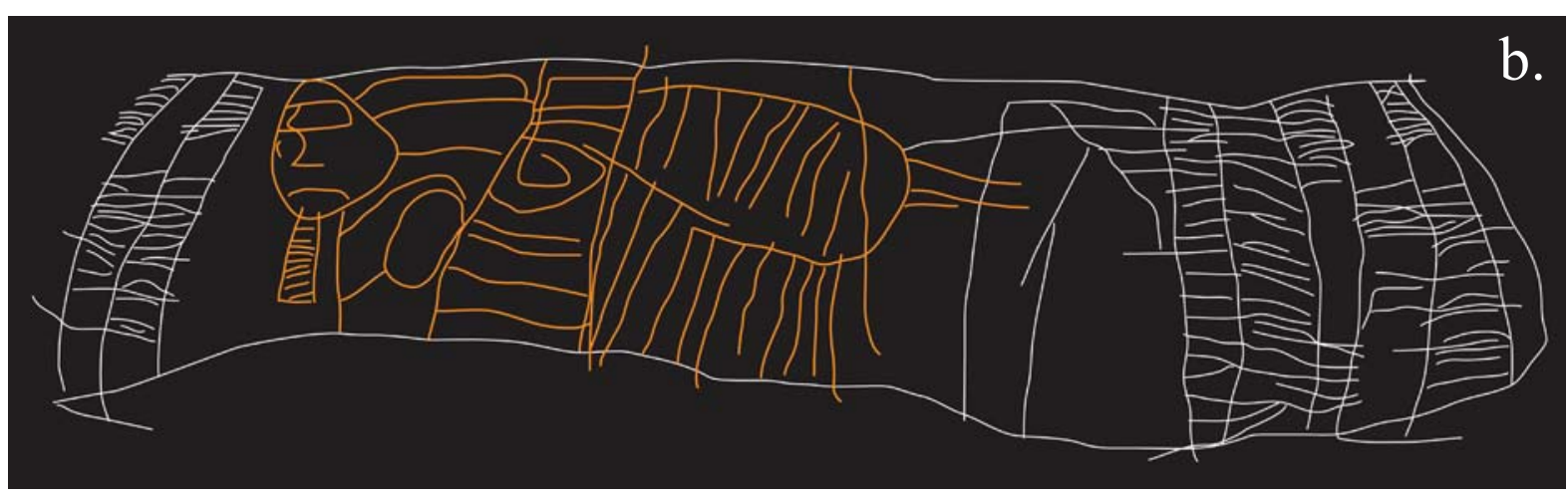

At the Crenshaw site, a late Fourche Maline and Early Caddo ceremonial center in southwestern Arkansas, 2042 antlers (representing a minimum of 1021 white-tailed deer) were carefully placed in pairs in a pile on the floor of a building that stood around A.D. 1000 (Schambach 2014). Ultimately, this temple went out of use, possibly it was burned down, and its remains were covered by a low mound. Although this is the only "antler temple" found so far in the Caddo area, we may suppose that similar ones existed at all the early Caddo ceremonial centers and that the spirits of the deer, whom the modern Caddo still consider "the closest thing to a human," demanded that their antlers be placed in these ritually important temples dedicated to the remains of deer.

Around 350 years later, someone, again probably a priest or shaman, placed the lower jaw (mandible) of a white-tailed deer on the otherwise clean floor of a Caddo temple just before it was ritually burned and incorporated into a "temple mound" at the Ferguson site near Emmet, Arkansas, about 40 miles northeast of Crenshaw.

Around 50 years after the burning of the temple at the Ferguson site, three buildings were ritually burned and subsequently incorporated into mounds at the Tom Jones site just northwest of Washington, Arkansas (2004-2005 Annual Report of the Arkansas Archeological Survey). In one of them, a deer scapula (shoulder blade) was placed next to the fire place and covered with a large pot before the building was burned. In the second building, two large deer scapulas were included in a mound before the building was burned. In the case of the third building, a collection of six deer scapulas were included in the mound that covered the remains of the building after it was burned.

These examples from Caddo mound sites in southwestern Arkansas, and the man-deer engraved vessel from an East Texas Caddo site discussed here, point to a complex relationship between Caddo peoples and deer. This relationship may never be fully understood. 


\section{References Cited}

Driver, H. E.

1961 Indians of North America. The University of Chicago Press, Chicago.

Griffith, W. J.

1954 The Hasinai Indians of East Texas as Seen by Europeans, 1687-1772. Philological and Documentary Studies, Vol. 2, No. 3. Middle American Research Institute, Tulane University, New Orleans.

Perttula, T. K., M. Walters, S. Marceaux, and B. Nelson

2009 Caddo Pottery Vessels and Pipes from Sites in the Middle and Upper Sabine and Upper Neches River Basins, Smith and Wood Counties, Texas. Special Publication No. 7. Friends of Northeast Texas Archeology, Pittsburg and Austin.

Schambach, F. F.

2014 Introduction to the Crenshaw Bioanthropological Project. The Arkansas Archeologist 52:1-15.

Underhill, R.

1967 Religion Among American Indians. In The North American Indians: A Sourcebook, edited by R. C. Owen, J. F. Deetz, and A. D. Fisher, pp. 96-109. The Macmillan Company, New York. 